J. Perinat. Med. 15 (1987) 531

\section{Balancing the risks of planned cesarean section and trial of vaginal delivery for the mature, selected, singleton breech presentation}

\author{
Francisco F. Songane ${ }^{1}$, Shatik Thobani' ${ }^{1}$, Himansugekhar Malik ${ }^{1}$, Paul Bingham², \\ and Richard J. Lilford ${ }^{1}$ \\ ${ }^{1}$ Department of Obstetrics and Gynecology, St. James's University Hospital, Leeds, \\ U.K. \\ ${ }^{2}$ Department of Obstetrics and Gynecology, Leicester General Hospital, Leicester, \\ U.K.
}

\section{Introduction}

A number of recent papers have reported encouraging results for vaginal delivery of carefully selected cases of mature singleton breech presentation $[1,3-5,7,8,10,14,15,18-22,27,32,33$, $38,41,45,46,49,51-53,55,56]$. Many of these authors recommend that their findings support a policy of selected vaginal breech delivery. Nevertheless, the series are frequently small and these conclusions may not be tenable if fetal morbidity and mortality rates, lower than those which can be demonstrated in these studies, are regarded as unacceptable. We have therefore analyzed 899 mature singleton breech presentations in order to provide a more precise estimate of the fetal risks of cesarean section and trial of vaginal delivery for breech presentation.

With few exceptions recent papers make no mention of the rate of failed trial of vaginal breech delivery. This is an important consideration because the maternal advantages of trial of vaginal delivery diminish as the intrapartum cesarean section rate rises. In this large study we therefore classified management according to the original decision to conduct an elective cesarean section or to attempt a trial of vaginal delivery. We ascertained the effect of changing practice during the study period on the proportion of trials of vaginal delivery which ended in cesarean section. We also evaluated the effects of epidural analgesia and maternal age on the outcome of labor.

\section{Curriculum vitae}

Dr. Francisco Ferreira SONGANE was born in 1954 in Chidenguele-Gaza Province (Mozambique), where he had his primary education and afterwards went to Inhambane and Maputo for his secondary studies. He graduated in medicine in December 1978 at Eduardo Mondlane University in Maputo, Mo-

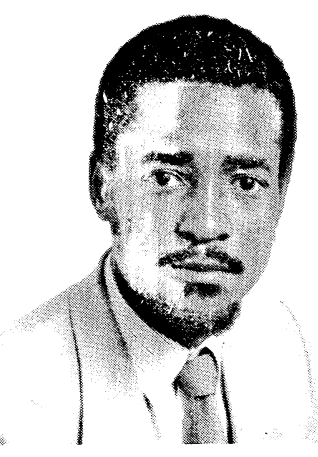
zambique, and in 1979 was appointed District Medical Officer in charge of a rural hospital until May 1981. In June $1981 \mathrm{Dr}$. SongaNe started his postgraduate training in obstetrics and gynecology at Maputo Central Hospital in the capital.

In February 1981 he participated in the III. Congress of the World Federation of Public Health Associations which was held in Calcutta, India, and was devoted to primary health care. In November 1983 he took part in a course regarding risk approach in maternal and child health care held in Rio de Janeiro, Brazil, organized by the PanAmerican Health Organisation. In May/June 1985 he went to Debrecen (Hungary) for a three week course on methods of family planning held in the Department of Obstetrics and Gynecology of Debrecen Medical School unter auspice of the W. H.O. In September 1985 he presented a paper entitled Maternal Mortality at Maputo Central Hospital at the XIth World Congress of Obstetrics and Gynecology held in West Berlin. Finally, in December 1985, Dr. SONGANE started a one year clinical attachment in obstetrics and gynecology at St. James's University Hospital, Leeds, England. 


\section{Material and methods}

A retrospective study was carried out to analyze cases of breech presentation at the St. James's Hospital from March 1976 to December 1984. Prior to March 1976 information was incomplete and the notes more difficult to trace.

The study included all cases of singleton breech presentation delivering after 36 weeks of gestation. In our hospital, trial of vaginal delivery is recommended for the mature selected vaginal breech presentation. The selection criteria are a clinically adequate pelvis, estimated fetal weight less than $4,000 \mathrm{~g}$, extended breech presentation and no serious medical or obstetric complications. In addition, X-ray pelvimetry is performed on the majority of patients and hyperextension of the fetal head and reduced pelvic dimensions are further contra-indications to vaginal delivery. In our hospital only erect lateral pelvimetry is performed to reduce the total radiation dose. The majority of vaginal deliveries and cesarean sections are managed with epidural analgesia. Labor is monitored by continuous cardiotocography. Vaginal delivery is by assisted breech delivery with forceps to the aftercoming head.

The method of delivery was recorded for each case and where cesarean section was carried out this was classified as elective, expedite (patients who underwent cesarean section as soon as they presented on the labor ward) or due to failure of vaginal trial. In the analysis of our data we included only deliveries after 36 weeks of gestation with a birth weight of over $2,000 \mathrm{~g}$.

For each case in the study, a printed form containing 52 items was completed from the casenotes.
The mother's age and parity was recorded, along with details of the delivery, presentation and method of analgesia. A large section was devoted to fetal outcome, including birth weight, sex, Apgar score at one and five minutes and admission to Special Care Baby Unit. In addition, any fetal trauma, anomaly and maternal morbidity was recorded.

To confirm the number of stillbirths and early neonatal deaths, a review of postmortem reports was carried out and two further early neonatal deaths were found in this way, thereby demonstrating the value of internal audit in retrospective studies of this type.

\section{Results}

Excluding twins and premature deliveries, 899 cases were analyzed.

\subsection{Elective and intrapartum cesarean section ra- tes}

Elective cesarean section was carried out in $24 \%$ of cases and in $7.6 \%$ the operation was carried out as soon as the patient presented on labor ward. Vaginal delivery was attempted in the remaining $68 \%$ of cases. It was successful in $78 \%$ of these, while the remaining $22 \%$ required surgery for a failed trial of labor. Of the total 899 patients on whom complete information is available, $52.9 \%$ delivered vaginally. The threshold for cesarean section has decreased dramatically over this study period. Thus for the period 1976$1980,14.4 \%$ of patients were delivered by elective operations and this rose to $33.4 \%$ for the period

Table I. Method of delivery in older and younger mothers.

\begin{tabular}{llcllll}
\hline \multirow{2}{*}{$\begin{array}{l}\text { Age } \\
\text { years }\end{array}$} & \multicolumn{2}{l}{ Trial of vaginal delivery } & Elective & Expedite & Total \\
\cline { 2 - 5 } & Vaginal delivery & Failed trial & Total & & & \\
\hline$<35$ & $54.3 \%$ & $15.8 \%$ & $70.1 \%$ & $22.5 \%$ & $7.2 \%$ & 841 \\
& $(26.1 \%)$ & $(11.1 \%)$ & $(37.3 \%)$ & $(12.0 \%)$ & $(4.0 \%)$ & \\
$>35$ & $32.7 \%$ & $6.8 \%$ & $39.6 \%$ & $46.5 \%$ & $13.7 \%$ & 58 \\
& & $(1.7 \%)$ & $(1.7 \%)$ & $(12.0 \%)$ & $(1.7 \%)$ & \\
\hline
\end{tabular}

Nulliparous patients in brackets

Chi-squared test on original values: Elective cesarean section was carried out more often than trial of vaginal delivery after age 35 than before $(p=.0000037 ; 1$ d. f.). Trial of vaginal delivery was no more likely to fail in older mothers $(p=0.5 ; 1 d-f$.). Expedite cesareans are those carried out on admission to labor ward e.g., undiagnosed breech presentation. 
Table II. Influence of birth weight in the method of delivery.

\begin{tabular}{lllll}
\hline Method of delivery & \multicolumn{2}{l}{ Weight in } & \multirow{2}{*}{ Not stated } \\
\cline { 2 - 5 } & $<3,500$ & $3,500-3,899$ & $\geqslant 3,900$ & 3 \\
\hline Vaginal delivery & 376 & 77 & 20 & 0 \\
Section for failed trial & 92 & 26 & 19 & 0 \\
Elective section & 150 & 52 & 15 & 0 \\
Expedite section & 53 & 10 & 60 & 3 \\
\hline Total & 671 & 165 & 60 \\
\hline
\end{tabular}

Comparing rows one and two, Chi-squared $=18.0,2 \mathrm{~d} . \mathrm{f} ., \mathrm{p}=.00012$. Thus labor is much more likely to fail if attempted with a heavier fetus. Comparing rows 1 and 2 combined (trial of vaginal delivery) with row 3, chisquared $=5.6,2 \mathrm{~d}$.f., $\mathrm{p}=.075$. Thus there is no statistical difference in the proportion of large babies ascribed to elective cesarean section or trial of vaginal delivery. Clinicians seem to be poor at recognizing this risk factor.

$1981-1984$ inclusive. Similarly, the proportion of failed trials of labor rose from $15.4 \%$ to $30.7 \%$ in this time.

Multiparous patients allowed a trial of vaginal delivery were more likely to be successful than nulliparous patients allowed a trial $-85.9 \%$ compared with $69.8 \%$. Table I shows that patients over the age of 35 are more likely to have elective cesarean sections but trial of labor is equally successful in this group.

$74.6 \%$ of babies weighed less than $3,500 \mathrm{~g}$ (table II) and trial of vaginal delivery was successful in $80.3 \%$ of those compared to only $51.3 \%$ where fetal birthweight exceeded $3,900 \mathrm{~g}$.

\subsection{Perinatal mortality according to management}

Fourteen stillbirths and 3 early neonatal deaths occurred among the mature, singleton, breech presentations included in this study. There were 3 lethal congenital abnormalities (all neural tube defects) and these all presented as antepartum stillbirths. There were 8 other antepartum stillbirths, 3 definite intrapartum deaths and 3 early neonatal deaths. All intrapartum stillbirths and neonatal deaths occurred amongst patients allocated to a trial of vaginal delivery and none of these were associated with congenital abnormalities.

The first intrapartum stillbirth (1976) was the result of fetal hypoxia during a trial of vaginal delivery. The second death (1976) occurred in the second stage of labor in a nulliparous patient with epidural analgesia; postmortem showed a 2,300 g baby with a tentorial tear. The third intrapartum stillbirth (1981) occurred during a vaginal delivery of a grand-multiparous patient; postmortem showed subdural and subarachnoid hemorrhage in a $4,800 \mathrm{~g}$ baby.

The first early neonatal death (1976) occurred in a multiparous patient whose $2,300 \mathrm{~g}$ baby was born vaginally with low Apgar scores. Postmortem showed intrapartum hypoxia, cerebral damage and meconium aspiration. The second neon-

Table III. Fetal injuries noted until discharge - excluding cases with major congenital abnormalities.

\begin{tabular}{|c|c|c|c|c|c|c|}
\hline Method of delivery & $\begin{array}{l}\text { Buttock } \\
\text { injury }\end{array}$ & $\begin{array}{l}\text { Fracture } \\
\text { of femur }\end{array}$ & $\begin{array}{l}\text { Fracture } \\
\text { of parietal } \\
\text { bones }\end{array}$ & $\begin{array}{l}\text { Bruised } \\
\text { legs }\end{array}$ & $\begin{array}{l}\text { Unilateral } \\
\text { dislocation of } \\
\text { hips or knee }\end{array}$ & $\begin{array}{l}\text { Facial } \\
\text { palsy }\end{array}$ \\
\hline Vaginal delivery & 5 & 1 & 1 & 3 & 6 & 1 \\
\hline Section for failed trial & 1 & 0 & 0 & 0 & 1 & 0 \\
\hline Elective section & 1 & 0 & 0 & 0 & 0 & 0 \\
\hline Expedite section & 0 & 0 & 0 & 0 & 0 & 0 \\
\hline
\end{tabular}

There were no brachial plexus injuries or fractured clavicles. 
atal death (1977) at 38 weeks $(2,700 \mathrm{~g})$ followed recorded mechanical difficulty with the aftercoming head during vaginal delivery. The third (1977) was also the result of hypoxia and cerebral damage of a $2,500 \mathrm{~g}$ baby following vaginal delivery. Thus, there were 6 intrapartum stillbirths and early neonatal deaths following 476 vaginal deliveries and 613 trials of vaginal delivery; rates of 1.26 and .98 per cent respectively.

\subsection{Fetal morbidity}

There were 31 anomalies of the limbs $(3.4 \%)$, most commonly congenital dislocation of both hips. Six neutral tube defects were encountered (3 lethal) and 2 cases of exompholos, 1 Down's syndrome and 2 cases of congenital heart defect.

Ninety per cent of all fetal trauma and all serious injuries followed vaginal delivery (table III). The relationship between Apgar score in normal babies and method of management (trial of vaginal delivery/elective/expedite cesarean section) is shown in table IV. It can be seen that Apgar scores at one minute are significantly lower in the trial of vaginal delivery group $(\mathrm{p}=0.000001)$. In addition, there were 3 cases of cerebral irritation in this series and all of these followed vaginal breech delivery. Other complications requiring admission to Special Baby Unit, such as meconium aspiration and hypothermia, were also more common in this group (table V). There was no correlation between the length of the second stage and 5 minute Apgar score or admission to a Special Care Baby Unit (table VI). There was no statistically significant association $(p=0.12)$ between second stage duration and one minute Apgar score.

\subsection{Reasons for cesarean section}

The indications for elective cesarean section are shown in table VII where it can be seen that concern over fetal or pelvic size, other complications or previous cesarean section were the commonest reasons for advising against a trial of labor. The reasons for a failed trial of labor are detailed in table VIII where poor progress was much the most common indication amongst both primiparous and multiparous patients. Interestingly, $32 \%$ of these operations for poor progress were carried out in the second stage of labor. It was not possible to ascertain whether the frequent occurrence of cesarean section in the second stage 

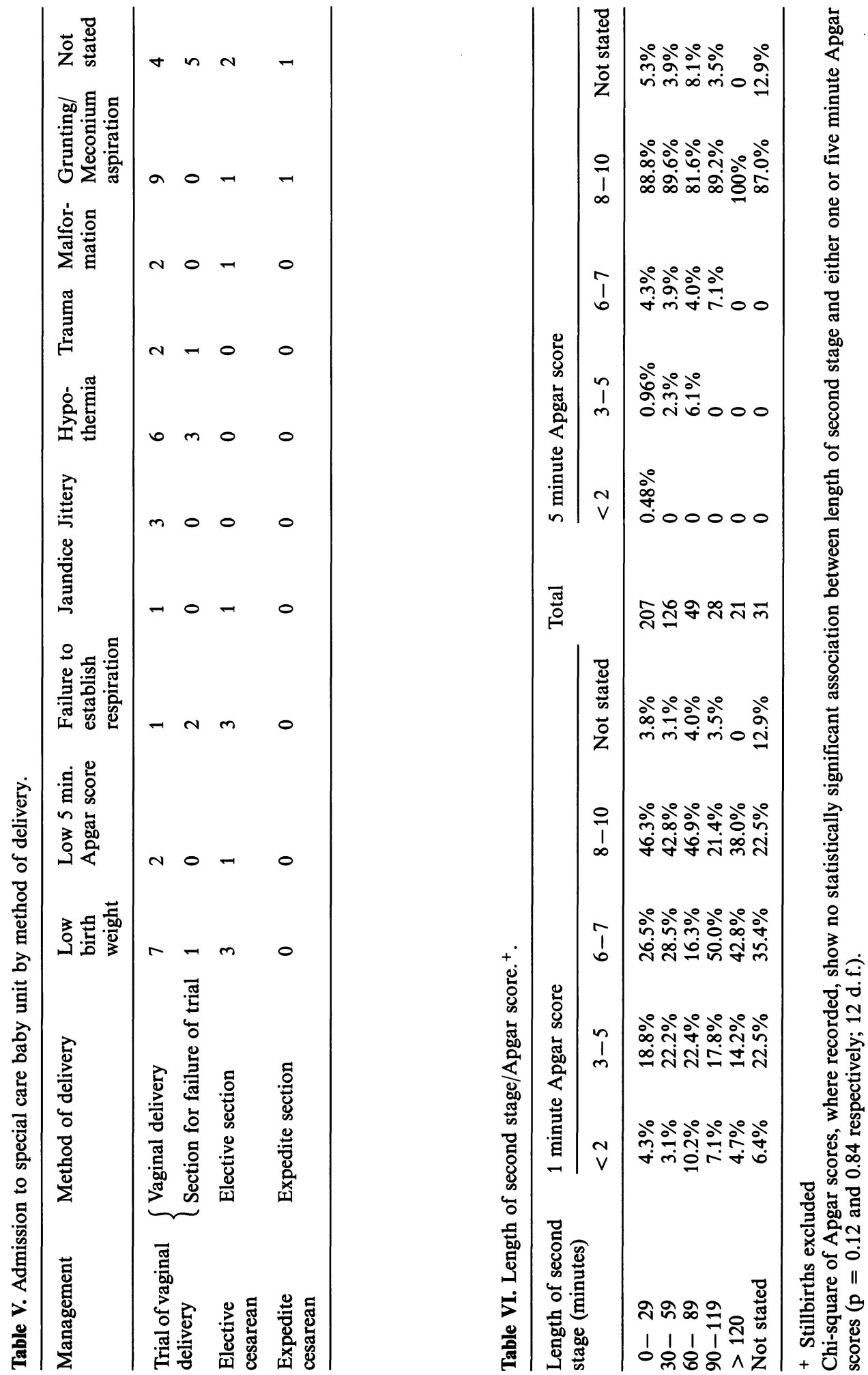
Table VII. Pelvimetry results in patients undergoing elective cesarean section.

\begin{tabular}{lccc}
\hline Reason for section & Pelvimetry done & No pelvimetry & Total \\
\hline Large baby/unfavorable pelvis & 69 & 2 & 71 \\
Previous section & 23 & 25 & 48 \\
Obstetric or medical complication & 51 & 44 & 95 \\
Non-frank presentation & 0 & 0 & 0 \\
Patient preference & 1 & 0 & 1 \\
\hline Total & 144 & 71 & 215 \\
\hline
\end{tabular}

N. B. 2 cases not stated

Table VIII. Reason for section in failed trial.

\begin{tabular}{lccr}
\hline Reason & Nulliparous (\%) & Multiparous (\%) & Total \\
\hline Fetal distress in 1st stage & $16(16.8)$ & $9(21.9)$ & 25 \\
No progress in 1st stage & $50(52.6)$ & $20(48.7)$ & 70 \\
Fetal distress in 2nd stage & $3(3.1)$ & 1 & $(2.4)$ \\
No progress in 2nd stage & $22(23.1)$ & $11(26.8)$ & 4 \\
Frank converted to footling & $3(3.1)$ & 0 & 3 \\
Prolapsed cord & 1 & 0 & 1 \\
\hline Total & 95 & 41 & 136 \\
\hline
\end{tabular}

N. B. One case due to raised blood pressure

Table IX. Length of recorded 2nd stage in patients with and without epidural analgesia.

\begin{tabular}{|c|c|c|c|c|c|c|c|}
\hline \multirow{2}{*}{$\begin{array}{l}\text { Duration } \\
\text { of second stage } \\
\text { (minutes) }\end{array}$} & \multicolumn{3}{|c|}{ Nulliparous } & \multicolumn{3}{|c|}{ Multiparous } & \multirow[t]{2}{*}{ Total } \\
\hline & $\begin{array}{l}\text { Epidural } \\
\text { analgesia }\end{array}$ & $\begin{array}{l}\text { No } \\
\text { epidural }\end{array}$ & $\begin{array}{l}\text { Sub- } \\
\text { total }\end{array}$ & $\begin{array}{l}\text { Epidural } \\
\text { analgesia }\end{array}$ & $\begin{array}{l}\text { No } \\
\text { epidural }\end{array}$ & $\begin{array}{l}\text { Sub- } \\
\text { total }\end{array}$ & \\
\hline $0-29$ & 26 & 29 & 55 & 64 & 88 & 152 & 207 \\
\hline $30-59$ & 51 & 17 & 68 & 47 & 19 & 66 & 134 \\
\hline $60-89$ & 37 & 9 & 46 & 14 & 2 & 16 & 62 \\
\hline $90-119$ & 13 & 0 & 13 & 2 & 0 & 2 & 15 \\
\hline$>120$ & 16 & 3 & 19 & 4 & 1 & 5 & 24 \\
\hline Not stated & 11 & 8 & 19 & 11 & 4 & 15 & 34 \\
\hline
\end{tabular}

There is a highly significant association between epidural analgesia and a prolonged second stage of labor; Mann Whitney $U-p=0.00002$

of labor was due to frequent use of epidural analgesia ( $62 \%$ of vaginal deliveries). Nevertheless, the duration of the second stage of labor was much greater after epidural analgesia (table IX).

The reasons for expedite cesarean section are shown in table X. Very few of these were indicated because patients presented in labor prior to the date assigned for elective surgery.

\section{Discussion}

The optimum method of delivery for a selected (that is low risk) mature singleton breech presentation has been the subject of considerable controversy. In the United States cesarean section is still the rule despite a swing towards vaginal delivery in some centers. In the U.K. vaginal delivery is advocated. This debate usually centers around the 
Table X. Reason for expedite section.

\begin{tabular}{llcr}
\hline Reason & Nulliparous & Multiparous & Total \\
\hline Fetal distress in labor on admission & 6 & 3 & 9 \\
Obstetric problem & 7 & 13 & 20 \\
Convertion to footling & 4 & 5 & 9 \\
Cord prolapse in a vaginal trial & 5 & 5 & 10 \\
Labor before the date for elective section & 2 & 5 & 7 \\
Unfavorable pelvis in labor at admission & 9 & 2 & 11 \\
Total & 33 & 33 & 66 \\
\hline
\end{tabular}

N. B. We include 3 cases where the breech presentation was not diagnosed at presentation in labor ward, but where cesarean section was arranged as soon as the diagnosis was made.

safety of vaginal breech delivery for the fetus compared to that of elective cesarean section. Proponents of vaginal delivery point out that the fetal risks, in carefully selected cases, are very low. The exact selection criteria are controversial $[2,6,11-$ $13,23,24,28-30,36,40,43,47,48,50,54]$ confirming that, as with other forms of obstetric risk prediction, this is a very inexact process. Nevertheless, many recent series report one or no fetal deaths in $80-200$ vaginal deliveries. In this series of 899 mature singleton breech presentations, trial of vaginal delivery was the selected method of management in $68 \%$ of cases. After excluding congenital abnormalities and stillbirths before the onset of labor, there were 6 deaths $(3$ intrapartum and 3 neonatal) in this group. This contrasts with no intrapartum or neonatal deaths of normal babies in the group managed by elective cesarean section. Thus, the rates of intrapartum fetal or neonatal loss were 9 per 1,000 following trial of vaginal delivery and 0 per 1,000 following elective cesarean section. Examination of postmortem reports and the clinical circumstances of these fetal losses indicates that they were all specific complications of labor which would normally be avoided by elective cesarean section. No fetus came to harm from a traumatic delivery during elective cesarean section or from premature birth. The latter should not occur in institutions, such as ours, which recommend dating scans for pregnancies at 16-18 weeks of gestation. If this information is not available, pulmonary maturity assessment on amniotic fluid should be considered. Although there was evidence, from post-mortem reports and clinical examinations, of asphyxia or traumatic delivery in all babies who died during or after vaginal delivery, these complications were not encountered in any of the fetuses who underwent cesarean section.
Our finding that a trial of vaginal delivery led to 9 deaths per 1,000 is compared with a review of literature over this last decade $[1,3,4,7,8,10$, $14,15,18-22,27,32,33,38,41,45,46,49,52$, $53,56]$ and a further series of 300 cases at Queen Charlotte's Hospital, London (submitted for publication). Nineteen deaths occurred among 4,160 vaginal deliveries and of these sixteen could be confidently ascribed to this method of delivery. Seven deaths were associated with 2,893 cesarean sections but 3 of these can be ascribed to failed trials of vaginal delivery. Assuming that $30 \%$ of cesarean sections took place during failed trials of vaginal delivery $(32.4 \%$ in this series) the fetal loss was

$$
\frac{16+3}{4,160+0.3(2,893)}=3.8 \text { per } 1,000 .
$$

Findings reported in the literature may represent the better end of medical practice.

It is fully conceded that the above studies and our own analysis may contain quantifiable and nonquantifiable selection bias. Thus, the issue of fetal safety would be best addressed by a randomised controlled study. This would have to be a large, multicenter, collaborative venture in order to avoid the type II error. To show a reduction to 1 per 1,000 from nearly 5 per 1,000 fetal and neonatal deaths which we have ascribed to trial of vaginal breech delivery in low-risk patients, at the .05 significance level, with $80 \%$ power, would require 2,950 patients in each arm of the study. As it is difficult to envisage a study of this size we need to examine existing data for obvious sources of bias. We suggest that amongst mature singleton presentations, all known sources of bias, after exclusion of congenitally abnormal fetuses, are likely to work in favor of trial of vaginal 
delivery. In other words these patients must surely represent an ultra-low-risk group and it is unlikely that high risk cases were consciously or subconsciously selected for trial of vaginal delivery rather than cesarean sections. Thus the very low number of intrapartum and early neonatal deaths following elective cesarean section in these series, despite the high-risk nature of many of the pregnancies, is further evidence of the greater safety of this method of delivery.

Assessment of fetal morbidity also showed greater risk associated with trial of vaginal delivery. We found that $13.8 \%$ of babies born by elective cesarean section had low Apgar scores (less than 6 at one minute) compared to $24.4 \%$ among vaginal deliveries and $23.4 \%$ among those with a failed trial. Thus, the percentage of low one minute Apgar scores among vaginal deliveries is almost twice that among patients delivered by elective cesarean section. (We would have liked to confirm this observation with epidural analgesia only, but anesthetic details were missing from many of the notes of patients coming to cesarean section). Similarly, after excluding congenital abnormalities, $5.5 \%$ of infants born to mothers who underwent elective cesarean section were admitted to a Special Care Baby Unit, while among those delivered vaginally and by cesarean section after failed trial the figures were 7.8 and $8.8 \%$ respectively and included the only cases of cerebral irritation in this study. The same trend emerges for other measures of fetal morbidity and again confirms impressions from the literature $[16,17,25,26,34$, 37].

An important point which is often omitted from the discussion is that the achievement of these relatively low fetal risks may require a very high intrapartum cesarean section rate. This issue is omitted in 23 of the 27 papers on breech delivery in the last decade. The four papers $[1,10,20,52]$ which do mention this show that a weighted mean of $31.4 \%$ of trials of vaginal delivery end in cesarean section. In our own series, $22 \%$ of trials of vaginal delivery ended in cesarean section. In the more recent half of the study period $31 \%$ of trials ended in cesarean section. Many proponents of vaginal breech delivery argue that any small increase in fetal risk is justified by the greater safety of vaginal delivery compared to cesarean section. This conclusion should be reanalyzed in light of the above failure rates for trial of vaginal breech delivery and the relative risks of intrapartum and elective cesarean section. Thus, the relative risk of direct maternal death following emergency surgery, after excluding maternal medical complications, was 4.5 times that of elective cesarean section in the Swedish study [35]. Similarly, the relative risk of direct maternal death from emergency cesarean section was six times that of elective cesarean section in the most recently published confidential enquiry into maternal mortality [44]. Emergency cesarean sections in this series, however, included operations performed for such hazardous conditions as severe preeclampsia and placenta praevia. However, even if these are excluded, the maternal mortality for intrapartum cesarean section for obstructed labor and fetal distress was four times that of mortality for repeat elective cesarean section and cesarean sections for malpresentation. Anesthetic deaths are four times as likely following emergency cesarean sections and deaths from thrombotic complications, even after excluding patients with other medical diseases, were six times as common following emergency procedures. It is thus reasonable to assume that cesarean section carried out for failed trial of vaginal breech delivery is four times as dangerous as that of elective cesarean section. It follows from this that the maternal mortality of trial of vaginal delivery reaches that of elective cesarean section when $16 \%$ of vaginal breech deliveries end in intrapartum cesarean section. We have seen that at least $28 \%$ of trials of vaginal breech delivery, with modern care, are likely to end in intrapartum cesarean section. The mortality rate for trial of vaginal breech delivery under these circumstances would equal that of elective cesarean section if intrapartum cesarean section was only three times as dangerous as elective operation. These calculations assume: 1) a maternal mortality of vaginal delivery of 0.03 per 1,000 and for cesarean section of 0.2 per 1,000 [44] and 2) a ratio of elective to intrapartum cesarean sections of $1: 2$ [9]. The calculation based on these assumptions, and showing that maternal mortality is the same with trial of vaginal delivery and elective cesarean section when the rate of failed trial of labor is $16 \%$, is shown in figure 1.

The above discussion does not take account of many other variables. Some patients assigned for elective cesarean section will arrive in the labor ward prior to their due date and we do not know the mortality of cesarean section performed as soon as labor starts and how this may affect the final conclusion. Furthermore, many patients having a trial of vaginal delivery with a breech 


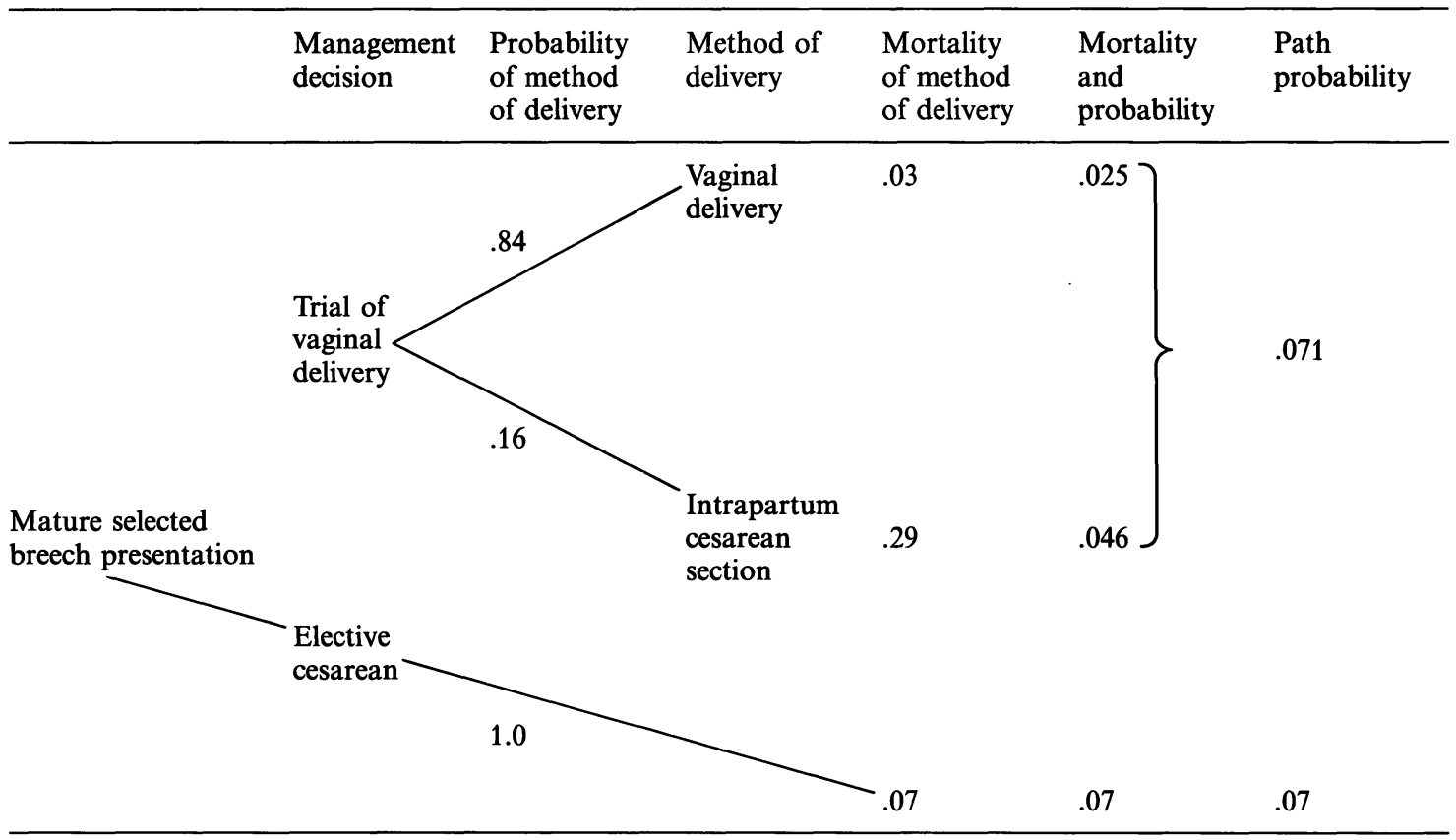

Figure 1. Threshold analysis showing that if:

1) $16 \%$ trials of vaginal delivery end in intrapartum cesarean section,

2) intrapartum cesarean section has 4 times the mortality of elective cesarean section,

3 ) the mortality of cesarean section in low risk patients is 0.2 per 1,000 and the ratio of elective to intrapartum cesarean section is $2: 3$,

4) the mortality of vaginal delivery in low risk patients is .03 per 1,000 ,

then the mortality of elective cesarean section is the same as that of trial of vaginal delivery.

This conclusion has many unquantified caveats (see text). Nevertheless, the failed trial of vaginal delivery rate in the second half of this series is $31 \%$, suggesting that trial of vaginal delivery is more dangerous for the mother's life - even if we have considerably over-estimated the relative risks of intrapartum versus elective cesarean section.

presentation will have apidural analgesia and the relative dangers of intrapartum compared to elective cesarean section may not be as great under these circumstances. The above mortality figures are based on all presentations, not specifically breech delivery. Thus, the dangers of both cesarean section and vaginal delivery are probably increased when the baby presents by the breech, but the relative order of magnitude is not known. Lastly, the relative effect of intrapartum and elective operations on the chance of wound dehiscence in a subsequent pregnancy are not known. At this point we wish merely to emphasize the overall concept that the high failure rate for trial of vaginal breech delivery quoted above considerably reduces the utility of trial of vaginal breech delivery. Furthermore our broad conclusion that trial of vaginal breech delivery may be more dangerous than elective cesarean section, is supported by the recent CPHA (Committee on Professional Hospital Authorities in the U.S.A.) [9] figures which included 98,192 breech presentations.

Our conclusions concerning the relative risks of elective and intrapartum surgery, as far as mortality is concerned, are also supported as far as major maternal morbidity is concerned. Thus, the only two previous reports to address this issue $[39,42]$ found the risk of major maternal morbidity was $5-6$ times as common following emergency as following elective cesarean section. Our conclusions, that mothers have less to loose by a policy of elective cesarean section than might be immediately apparent is well supported by existing data.

Many of the other findings in this series are in broad agreement with other authors although we found a lower incidence of lethal congenital abnormality - this is normally quoted as 6 times 
that for vaginal delivery $[3-5,10,15,18-21,32$, $33,38,41,45,49,51-53]$. Breech delivery should be preceded by a detailed anomaly scan as a severe or lethal defect may affect the subsequent management. Our findings confirm those of others which have shown that the second stage is prolonged in patients who receive epidural analgesia $[6,11,13]$. Of course, this is a potentially biased finding as patients with poor progress are more likely to require epidural analgesia. We also confirmed that where the baby is large, trial of vaginal delivery is less likely to be successful. Older mothers were more likely to be offered cesarean section but trial of vaginal delivery, if attempted, was equally successful. Patients with a large fetus were not more likely to be offered cesarean section. This factor is clearly difficult to recognize accurately antenatally, as anticipated excess fetal size was the most common stated reason for elective cesarean section. This again shows that risk prediction is an imprecise exercise although errors might be reduced, but not eliminated, by more frequent use of ultrasound weight estimation.

What conclusions can we draw from this study? Firstly the number of patients with a mature signleton breech presentation who are delivered vaginally is small and declining. Not only do $34 \%$ now undergo planned cesarean section, but trial of labor in the remainder is unsuccessful in approximately a third of cases. Despite this high degree of selection prior to the onset of labor and during labor itself, vaginal delivery carries a substantial risk to the fetus. Thus, our own study

\section{Summary}

The experience of mature, singleton, vaginal breech delivery over the last decade in our hospital is reviewed. This constitutes the largest series of breech delivery reported for over twelve years. Unlike all but two previous reports, we analyze our results by management policy; elective cesarean section, trial of vaginal breech delivery and cesarean section as soon as the diagnosis of breech delivery was made on labor ('expedite' cesarean operations). Six intrapartum or neonatal deaths occurred among 613 patients selected for trial of vaginal delivery - a rate of one per cent. There were none following 217 elective or 69 expedite cesarean sections. A detailed review of the literature over the last decade confirms that trial of vaginal delivery is more dangerous to the fetus and results in about one perinatal death of a normally formed infant in 200 deliveries. Apgar scores were slightly lower following trial of vaginal delivery and there were more irritable or injured babies in this indicates that fetal distress, prolapsed cord and, above all, entrapment of the aftercoming head will lead to perinatal death in nearly $1 \%$ of cases where trial of vaginal delivery is carried out. This figure may be falling, but at the expense of higher intrapartum cesarean section rates and we have seen that this substantially increases the overall risk to the mother. Thus the last perinatal death related to vaginal delivery in this series occurred in 1981, but intrapartum cesarean section rates have risen to $30.7 \%$. One third of these are carried out in the second stage of labor, when the maternal dangers of the operation may be greater still. Thus, we conclude that trial of vaginal breech delivery is more likely to be harmful to the fetus than elective cesarean section and that it carries no advantage to the mother in terms of mortality and major morbidity for the current pregnancy. Nevertheless, elective cesarean section may deprive the patient of the emotional benefits which many women experience from vaginal delivery. In addition this management is less likely to lead to a uterine scar with its implications for further pregnancies [31]. We therefore believe that our findings do not preclude the use of trial of vaginal delivery in lower risk mothers. By the same token we feel that many mothers may prefer an elective cesarean section and that it is quite reasonable to offer this in all cases. Mothers who do not have strong feelings about natural childbirth or who do not wish to run any increased risk with their present pregnancy, in order to avoid a uterine scar, should have the option of elective surgery.

group. The last intrapartum or neonatal death occurred in 1981. However, the elective cesarean section rate has increased from 14 to 33 per cent over this time period. Similarly the rate of failed trial of vaginal breech delivery has increased from 15 to 31 per cent. The proportion of failed trials was highest where the fetus was large but clinicians were poor at estimating fetal weight. Decision theory is used to examine the maternal utility of trial of vaginal breech delivery versus elective cesarean section when the intrapartum cesarean rate rises to these levels. It is shown that, from the point of view of maternal mortality and morbidity in the current pregnancy, trial of vaginal delivery maybe the more dangerous maternal option. Thus a low threshold for cesarean section in labor leads to greater fetal safety at the mother's expense. It is nevertheless concluded that maternal attitude and the long-term effects of a uterine scar should be considered in the final decision.

Keywords: Cesarean section, trial of vaginal delivery. 


\section{Zusammenfassung}

Abwägen der Risiken zwischen dem geplanten abdominellen Kaiserschnitt und dem Versuch einer vaginalen Entbindung beim reifen, ausgewählten Einling aus Beckenendlage Die Erfahrungen bei der vaginalen Entbindung bei reifen Einlingen aus Beckenendlage (BEL) an unserer Klinik sind aus den letzten 10 Jahren zusammengetragen worden. Dies ist die umfangreichste Sammlung von Geburten aus BEL seit über 12 Jahren. Im Gegensatz zu allen außer zwei der vorhergehenden Studien werten wir unsere Ergebnisse nach dem Vorgehen aus; elektiver Kaiserschnitt, Versuch einer vaginalen Entbindung aus BEL und Kaiserschnitt, sobald die Diagnose einer BEL während der Wehen gestellt wurde (,beschleunigter“ Kaiserschnitt).

Sechs intrapartale oder neonatale Todesfälle traten bei 613 Patientinnen auf, die für den Versuch einer vaginalen Entbindung ausgewählt wurden, ein Anteil von 1\%. Bei den 217 elektiven und 69 beschleunigten Kaiserschnitten traten keine Todesfälle auf. Eine sorgfältige Studie der Literatur aus dem letzten Jahrzehnt bestätigt, daß der Versuch einer vaginalen Entbindung gefährlicher für das Kind ist und daß er in ungefähr einer von zweihundert Geburten zum perinatalen Tod eines normal entwickelten Säuglings führt. Die Apgar-Werte waren nach einer vaginalen Entbindung geringfügig niedriger, und es gab auch mehr gestörte oder verletzte Kinder in dieser Gruppe. Der letzte neonatale oder intrapartale Todesfall trat 1981 auf. Jedoch hat die Rate der elektiven Kaiserschnitte in diesem Zeitraum von 14 auf 33\% zugenommen. Ähnlich hat sich die Rate von mißlungenen Versuchen vaginaler Entbindungen von 15 auf $31 \%$ erhöht. Der Anteil an mißlungenen Versuchen war in den Fällen am größten, in denen der Fetus schwer, die Kliniker aber schlecht in der pränatalen Gewichtsbeurteilung waren. Bei Anstieg der Rate der intrapartalen Kaiserschnitte auf diese Anzahl wurde zur Entscheidungsfindung zwischen mütterlichem Nutzen für den Versuch einer vaginalen BEL-Entbindung und dem elektiven Kaiserschnitt theoretisch abgewogen. Es hat sich gezeigt, $\mathrm{da} ß$ aus der Sicht der mütterlichen Mortalität und Morbidität in der bestehenden Schwangerschaft der Versuch einer vaginalen Entbindung die gefährlichere mütterliche Wahl darstellen kann. Eine niedrige Schwelle bei der Entscheidung für einen Kaiserschnitt bei vorhandenen Wehen führt daher zu einer höheren fetalen Sicherheit auf Kosten der Mutter.

Trotzdem sei abschließend gesagt, daß die mütterliche Einstellung und die Langzeiteffekte einer uterinen Narbe bei der endgültigen Entscheidung berücksichtigt werden sollten.

Schlüsselwörter: Kaiserschnitt, Versuch der vaginalen Entbindung.

\section{Résumé}

Comparaison des risques de la césarienne programmée et de la tentative d'accouchement par voie basse pour le siège unique, maturé et selectionné

Nous avons étudié notre expérience de l'accouchement du fœtus unique en présentation du siège par voie vaginale au cours de la dernière décénnie dans notre hôpital. Il s'agit de la série la plus importante d'accouchements par le siège au cours de douze années. Nous analysons nos résultats en fonction de la politique de prise en charge contrairement à toutes les autres études sauf deux: césarienne programmée, tentative d'accouchement par le siège par voie basse et césarienne dès que le diagnostic de siège est porté en cours de travail (césarienne en urgence).

Il y a six morts perpartum ou néonatales chez les 613 patientes sélectionnées pour un essai d'accouchement par voie basse - donc une fréquence de $1 \%$. On n'a pas observé de telles morts parmi les 217 césariennes programmées et les 69 césariennes en urgence. Une étude approfondie de la littérature de la dernière décénnie confirme que l'éssai d'accouchement par voie basse est plus dangereux pour le fotus et qu'il aboutit à une mort périnatale d'un enfant non porteur de malformation sur 200 accouchements. Les scores d'Apgar sont légèrement inférieurs après la voie basse et il y a plus d'enfants avec des signes d'irritation ou traumatisés dans ce groupe. La dernière mort per-partum ou néonatale remonte à 1981. Toutefois, le pourcentage de césariennes programmées est passé de 14 à 33 pour cent sur cette période. De même, le taux d'échecs de tentative d'accouchements par le siège par voie basse est passé de 15 à $31 \%$. La proportion d'échecs de l'accouchement par voie basse est plus grande lorsque le fetus est gros mais les médecins ont du mal à estimer le poids fæatal. La théorie de la décision est utilisée pour étudier l'utilité pour la mère de l'essai d'accouchement du siège par voie basse par rapport à la césarienne programmée, alors que le taux de césariennes en cours de travail s'élève à de tels niveaux. On montre que, si l'on se place du point de vue de la mortalité et de la morbidité maternelles au cours de la grossesse habituelle, l'essai d'accouchement par voie basse est peut-être l'option la plus dangereuse pour la mère. Ainsi un faible niveau de césarienne en cours de travail entraîne une sécurité fotale plus élevée au dépend de la mère.

On en conclue néanmoins que l'attitude de la mère et les effets à long terme de la cicatrice utérine devraient entrer en compte pour la décision finale.

Mots-clés: Césarienne, essai d'accouchement par voie vaginale. 


\section{References}

[1] Anderman S, A Ellenbogen, OE JaschevatzKy, S. GRUNSTEIN: Is the breech presentation in primigravida an absolute indication of Cesarean section?: Eur J Obstet Gynecol Reprod Biol 18 (1984) 11

[2] Ballas S, R Toaff, AJ Jaffa: Deflexion of the fetal head in breech presentation. Incidence, management and outcome. Obstet Gynecol 52 (1978) 653

[3] Bilodeau R, R Marier: Breech presentation at term. Am J Obstet Gynecol 130 (1978) 555

[4] BIRD CC, TW McElIN: A six-year prospective study of term breech deliveries utilizing the Zatuchni-Andros Prognostic Scoring Index. Am J Obstet Gynecol 121 (1975) 551

[5] Bistoletti P, H Nisell, C Palme, H Lagercrantz: Term breech delivery: Early and late complications. Acta Obstet Gynecol Scand 60 (1981) 165

[6] Bowen-Simpkins P, IL FeRgusSon: Lumbar epidural block and the breech presentation. $\mathrm{Br} \mathrm{J}$ Anaesth 46 (1974) 420

[7] Bowes WA, ES TAYLOR, M O'BRIEN, C BOWES: Breech delivery: Evaluation of the method of delivery on perinatal results and maternal morbidity. Am J Obstet Gynecol 135 (1979) 965

[8] Breeson AJ, GT Koracs, BG Pickles, JG Hill: Extradural analgesia - the preferred method of analgesia for vaginal breech delivery. Br J Anaesth 50 (1978) 1227

[9] Caesarean Childbirth. Commission on Professorial and Hospital Activities (CPHA). Government Printing Office (DHSS Publicator No. NIH 822067), Washington D. C. 1980

[10] Collea JV, C Chein, EJ Quilligan: The randomised management of term frank breech presentation: A study of 208 cases. Am J Obstet Gynecol 137 (1980) 235

[11] CRAWFord JS: An appraisal of lumbar epidural blockade in patients with a singleton fetus presenting by the breech. J Obstet Gynaecol Br Comm 81 (1974) 867

[12] Crawford JS, JB Weaver: Anaesthetic management of twin and breech deliveries. Clin Obstet Gynecol 0 (1982) 291

[13] Darby S, CA Thornton, DJ Hunter: Extradural analgesia in labour when the breech presents. $\mathrm{Br} \mathrm{J}$ Obstet Gynaecol 83 (1976) 35

[14] De Crespigny LJ, RJ PepPerell: Perinatal mortality and morbidity in breech presentation. Obstet Gynecol 53 (1979) 141

[15] Duignan N: Breech delivery. Has it a place in modern obstetrics? J Matern Child Health 482 (1980) 4

[16] Faber-NiJholt R, HJ HuisJes, BC TOuwen, VJ FIDLER: Neurological follow-up of 281 children born in breech presentation: a controlled study. $\mathrm{Br}$ Med J 286 (1983) 9
[17] FIANU S: Fetal mortality and morbidity following breech delivery. Acta Obstet Gynecol Scand [Suppl] 56 (1976) 7

[18] Gimovsky ML, RH Petrie, WD TodD: Neonatal performance of the selected term vaginal breech delivery. Obstet Gynecol 56 (1980) 687

[19] GimovsKy ML, RH PAUL: Singleton breech presentation in labour: Experience in 1980. Am J Obstet Gynecol 143 (1982) 733

[20] Gimovsky ML, RL Wallace, BS Schifrin, RH PAUL: Randomised management of the nonfrank breech presentation at term: A preliminary report. Am J Obstet Gynecol 146 (1983) 34

[21] Graves WK: Breech delivery in twenty years of practice. Am J Obstet Gynecol 137 (1980) 229

[22] Green JE, F McLean, LP SMith, R Usher: Has an increased cesarean section rat for term breech delivery reduced the incidence of birth asphyxia, trauma and death? Am J Obstet Gynecol 142 (1982) 643

[23] Hall JE, S KoHL: Breech presentation. A study of 1,456 cases. Am J Obstet Gynecol 72 (1956) 977

[24] HelfFerick M, J Favier: Breech delivery. Am J Obstet Gynecol 110 (1971) 58

[25] HuchCroft SA, MP Wearing, CW Buck: Late results of Cesarean and vaginal delivery in cases of breech presentation. Can Med Assoc J 125 (1981) 726

[26] Hochuli E, O Dubler, E Bornhauser, E Schoop: The development of children born by vaginal or abdominal breech delivery. Geburtshilfe Frauenheilkd 37 (1977) 4

[27] JafFa AF, MR Peyser, S Ballas, R ToafF: Management of term breech presentation in primagravidae. Br J Obstet Gynaecol 88 (1981) 721

[28] JoHnson CE: Breech presentation at term. Am J Obstet Gynecol 106 (1970) 865

[29] Joyce DN, F Giwa-Osagie, G SteVenson: Role of pelvimetry in active management of labour. $\mathrm{Br} \mathrm{Med}$ J 271 (1975) 505

[30] KaUPPILA O: The perinatal mortality in breech deliveries and observations on affecting factors. Acta Obstet Gynecol Scand [Suppl] 54 (1975) 39

[31] LAVIN JP, RJ STEVENS, M MIODOVNIK, TP BARDEN; Vaginal delivery in patients with a prior Cesarean section. Obstet Gynecol 59 (1982) 135

[32] LyONS ER, FR PAPSIN: Cesarean section in the management of the breech presentation. Am J Obstet Gynecol 130 (1978) 558

[33] ManN LI, JM Gallant: Modern management of the breech delivery. Am J Obstet Gynecol 134 (1979) 611

[34] MANZKe $\mathrm{H}$ : Morvidity among infants born in breech presentation. J Perinat Med 6 (1978) 127

[35] Moldin P, K Hokegard, TF NiElsen: Cesarean section and maternal mortality in Sweden 19731979. Acta Obstet Scand 63 (1984) 7 
[36] NeILSON DR: Management of the large breech infant. Am J Obstet Gynecol 107 (1970) 345

[37] NeLIGAN GA: The quality of the survivors of breech delivery in a geographically defined population. 5th Eur Congr Perinatal Med 1976

[38] NeMCOCK JC: Breech delivery in the primigravida: vaginal versus cesarean section. JAMA 78 (1979) 479

[39] Nielsen TF, KH Hokegard: Postoperative Cesarean section morbidity: A prospective study. Am J Obstet Gynecol 146 (1983) 911

[40] OHLSEN H: Outcome of term breech delivery in primigravidae. A feto pelvic breech index. Acta Obstet Gynecol Scand 54 (1975) 141

[41] O'LeARY J: Vaginal delivery of the term breech. Obstet Gynecol 53 (1979) 341

[42] PATEK E, B LARsson: Cesarean section. Acta Obstet Gynecol Scand 57 (1978) 245

[43] RACKER DC: Breech presentation in the elderly primipara. J Obstet Gynaecol 50 (1943) 352

[44] Report on confidential equiries into maternal deaths in England and Wales 1979-1981. Her Majesty's Stationery Office. London 1986

[45] Ridley WJ, P Jackson, JH Stewart, P Boyle: Role of antenatal radiography in the management of breech deliveries. Am J Obstet Gynecol 89 (1982) 342

[46] Rosen MG, L CHIK: The effect of delivery route on outcome in breech presentation. Am J Obstet Gynecol 148 (1984) 909

[47] Rovinsky JR, JA Miller, S KAPLAN: Management of breech presentation at term. Am J Obstet Gynecol 115 (1973) 497

[48] SNOEK J, R CANON: Considerations sur la conduite a tenir et le pronostic pour l'enfant des presentations du siege chez les primipares agees. Brux Med 19 (1939) 1235
[49] TATUM RK, JW ORR, S SoONG, JF Huddleston: Vaginal breech delivery of selected infants weighing more than 2,000 grams. Am J Obstet Gynecol 152 (1985) 145

[50] TODD WD, CM STEER: Term breech: review of 1,006 term breech deliveries. Obstet Gynecol 22 (1963) 583

[51] Ulstein M: Breech delivery. Ann Chir Gynaecol 69 (1980) 70

[52] WATSON WJ, WL BENSON: Vaginal delivery for the selected frank breech infant at term. Obstet Gynecol 64 (1984) 638

[53] WeAver J: Breech delivery - obstetric outcome. Proceedings of the Scientific Meeting of the Royal College of Obstetricians and Gynaecologists 1980

[54] Westgren M, H Grundsell, I Ingemarsson, A MuHLOW, NW SVENNIGSEN: Hyperextension of the fetal head in breech presentation. A study with long-term follow up. $\mathrm{Br}$ J Obstet Gynaecol 88 (1981) 101)

[55] WOLTER DF: Patterns of management with breech presentation. Am J Obstet Gynecol 125 (1976) 733

[56] Woo JS, PH Chan, A GHosh, V Wong, HK MA: Term breech delivery - is a high Cesarean section rate justified? Aust NZ J Obstet Gynaecol 23 (1983) 25

Received September 27, 1986. Accepted February 9, 1987.

Richard J. Lilford, M. D.

Professor in Obstetrics \& Gynecology

The University of Leeds

Department of Obstetrics and Gynaecology

St. James's University Hospital

Leeds LS9 7TF, U. K. 